UDC 541.183:547:211:539.104

\title{
EFFECTS OF GAMMA-IRRADIATION ON NANOSTRUCTURED Na-BENTONITE SILICATE LAYERS AT ROOM TEMPERATURE
}

\author{
M.K. Ismayilova \\ Azerbaijan National Academy of Sciences, Laboratory of Energy Consuming Radiation \\ Processes, Institute of Radiation Problems, Baku, Azerbaijan \\ E-mail: ismayilovamehpara@gmail.com
}

The aim of this paper to study the effects of $\gamma$-rays on nanostructured Na-bentonite clay from Alpoid deposit. The effect of high doses (up to $256 \mathrm{kGy}$ ) of $\gamma$-radiation on the short-range structural organization in montmorillonite was studied using infrared spectroscopy. Significant change attributable to irradiation was observed at dose of $57 \mathrm{kGy}$. No significant changes were observed after $57 \mathrm{kGy}$ of $\gamma$-radiation. A small variation in the water content was noted but it is not systematic. The results show that the montmorillonite structure can accumulate high doses of radiation with damage. The modifications most likely to be generated by the radiation were expected to be within the silicate layers. The morphology of the nanocomposites was studied with scanning electron microscopy. In this paper, the effects of ionizing radiation on the Na-bentonite clay investigated by FT-IR method. These spectra show the suitability of FT-IR study of mineral surfaces and the changes in the spectra brought about by the surface phenomena.

\section{INTRODUCTION}

The two most common modification methods of clay minerals are thermal modification and acid activation. This study aims at examining a novel insight to characterize bentonites to find out the mineralogical and physicochemical properties of irradiated $\mathrm{Na}$-bentonite clay samples. Bentonite is rich in montmorillonite, which is a nanostructured and nanoporous member of smectite group. Mineralogical and physicochemical properties of bentonites play a key role in choosing appropriate bentonites for different applications. Based on their chemical composition and particle morphology, clays are organized into several classes such as smectite, chlorite, kaolinite, illite and halloysite [1]. Due to their wide availability, relatively low cost and relatively low environmental impact, nanoclays have been studied and developed for various applications [2]. With the rapid growth of nanotechnology, clay minerals are increasingly used as natural nanomaterials [3]. Nanoclays are nanoparticles of layered mineral silicates with layered structural units that can form complex clay crystallites by stacking these layers [4]. An individual layer unit is composed of octahedral and/or tetrahedral sheets [5]. Octahedral sheets consist of aluminum or magnesium in a six-fold coordination with oxygen from a tetrahedral sheet and with hydroxyl. Tetrahedral sheets consist of silicon-oxygen tetrahedra linked to neighboring tetrahedra, sharing three corners while the fourth corner of each tetrahedron sheet is connected to an adjacent octahedral sheet via a covalent bond [6]. Based on their mineralogical composition, there are approximately 30 different types of nanoclays, which depending on their properties are used in different applications [7]. The most common plate-like montmorillonite (MMT) nanoclay (smectite) consists of approximately one $\mathrm{nm}$ thick aluminosilicate layers surface-substituted with metal cations and stacked in approximately $10 \mu \mathrm{m}$ sized multilayer stacks [8-11]. Clays are hydrous aluminosilicates broadly defined as those minerals that make up the colloid fraction of soils, sediments, rocks, and water [12] and may be composed of mixtures of fine-grained clay minerals and clay-sized crystals of other minerals such as quartz, carbonate, and metal oxides. Clays play an important role in the environment by acting as a natural scavenger of pollutants by taking up cations and anions either through ion exchange or adsorption or both. Thus, clays invariably contain exchangeable cations and anions held to the surface. Van Olphen [13] has cited several types of active sites in clays, namely, (i) Bronsted acid or proton donor sites, created by interactions of adsorbed or interlayer water molecules, (ii) Lewis acid or electron acceptor sites occurring due to dehydroxylation, (iii) oxidizing sites, due to the presence of some cations in octahedral positions or due to adsorbed oxygen on surfaces, (iv) reducing sites produced due to the presence of some cations, and (v) surface hydroxyl groups, mostly found in the edges, bound to $\mathrm{Si}, \mathrm{Al}$, or other octahedral cations. Clays have been good adsorbents because of the existence of several types of active sites on the surface, which include Bronsted and Lewis acid sites and ion exchange sites. The edge hydroxyl groups have been particularly active for various types of interactions. Clays and modified clays have been found particularly useful for adsorption of heavy metals. Clays have received attention as excellent adsorbents of $\mathrm{As}, \mathrm{Cd}, \mathrm{Cr}, \mathrm{Co}, \mathrm{Cu}, \mathrm{Fe}, \mathrm{Pb}, \mathrm{Mn}, \mathrm{Ni}$, and $\mathrm{Zn}$ in their ionic forms from aqueous medium. The adsorption capacities differ from metal to metal and also depend on the type of clay used [14]. For this research, raw bentonite was used from the Alpoid deposit in Azerbaijan. It is one of highest quality natural sodium bentonite deposits in the world. The deposit consists of montmorillonite and hydromica-montmorillonite clay.

The Alpoid deposit contains more than $85 \%$ of montmorillonite -

$(\mathrm{Na}, 0.5 \mathrm{Ca}) 0.7(\mathrm{Al}, \mathrm{Mg}, \mathrm{Fe}) 4(\mathrm{Si}, \mathrm{Al}) 8 \mathrm{O} 20(\mathrm{OH}) 4 \cdot \mathrm{xH}_{2} \mathrm{O}$, where $\mathrm{Na}$ and $\mathrm{Mg}$ - cations prevail in CEC. Exchanged cations content makes $92 . .98 \mathrm{meq} / 100 \mathrm{~g} \mathrm{[15-17].} \mathrm{The}$ 
Cambrian clay minerals, being high-alkaline minerals caused activation of the water radiolysis process. Interlayer links destruction will take place at low enough radiation doses [18]. Alpoid clays are also highalkaline minerals [15-17]. Gamma radiation may alter the surface characteristics of bentonite [19]. In heterogenous reactions were used modified activated hydrated aluminasilicates as catalyst. In addition, irradtion of Na-bentonite clay from Alpoid deposit by $\gamma$-rays is not studied before.

\section{EXPERIMENTAL PART}

Clay samples was taken from the Alpoid deposit. Alpoid bentonite deposit which excels considerably in quality such bentonite deposits as in Greece, Turkey, India and China and is equal to the benchmark Wyoming bentonite. Alpoid deposit is located in a northwest part of the Gazakh region. It is one of the high-quality natural sodium bentonite deposits in the world and is represented by one flat-lying seam with no poor rocks inside. It relates to sedimentary type formed as a result of continental - lacustrine conditions. The deposit is represented by montmorillonite and hydromica-montmorillonite clay.

The morphology of the nanostructured was studied with scanning electron microscopy (SEM from ZEISS, Leo 1530 VP) and EDX (ZEISS, Gemini 1000). EDX spectra were measured of a closed powder area of about $1 \times 1 \mathrm{~mm}$. The raw bentonite clay sample used in these experiments has nanostructured composition with particle size in the range of $55 \leq \mathrm{d}[\mathrm{nm}] \leq 175 \mathrm{~nm}$ [20]. Clay samples were packed in a closed Pyrex glass container. The bentonite clay samples were irradiated with gamma radiation from the ${ }^{60} \mathrm{Co}$ isotope under static conditions, within vacuum sealed quartz tubes at room temperature. The dose rate was $10.5 \mathrm{rad} / \mathrm{s}$. The irradiated and unirradiated samples were characterized by FT-IR spectroscopy. Spectrophotometric measurements were performed in a VARIAN 640-IR spectrophotometer in the $4000 \ldots 400 \mathrm{~cm}^{-1}$ region. Reaction conditions: Given amount of catalystbentonite sample $(2 \mathrm{~g})$ was added in glass ampules and sealed, then subjected to various doses of radiation energy (from 1 to $256 \mathrm{kGy}$ ). They were irradiated for various periods of time. Radiation carried out for $1 \ldots 300 \mathrm{~h}$ at room temperature.

\section{RESULTS AND DISCUSSION}

Chemical composition of bentonite clays mined from the Alpoid deposit has the following characteristics (Table 1) $[15,16]$.

Table 1

Chemical composition of bentonite clays mined from the Alpoid deposit

\begin{tabular}{|c|c|c|c|}
\hline $\begin{array}{c}\text { Chemical } \\
\text { compound }\end{array}$ & $\begin{array}{c}\text { Percentage, } \\
\%\end{array}$ & $\begin{array}{c}\text { Chemical } \\
\text { compound }\end{array}$ & $\begin{array}{c}\text { Percentage, } \\
\%\end{array}$ \\
\hline $\mathrm{SiO}_{2}$ & 58.60 & $\mathrm{MgO}$ & 2.30 \\
\hline $\mathrm{Al}_{2} \mathrm{O}_{3}$ & 13.40 & $\mathrm{P}_{2} \mathrm{O}_{5}$ & 0.11 \\
\hline $\mathrm{Fe}_{2} \mathrm{O}_{3}$ & 4.70 & $\mathrm{SO}_{3}$ & 0.25 \\
\hline $\mathrm{FeO}$ & 0.18 & $\mathrm{~K}_{2} \mathrm{O}$ & 0.39 \\
\hline $\mathrm{TiO}_{2}$ & 0.39 & $\mathrm{Na}_{2} \mathrm{O}$ & 2.30 \\
\hline $\mathrm{CaO}$ & 2.05 & $\mathrm{PPP}$ & 15.33 \\
\hline Total & - & - & 100 \\
\hline
\end{tabular}

The SEM images of clay samples are shown in Fig. 1. SEM micrographs show an inhomogeneous consistency: larger particles $>2 \mu \mathrm{m}$ (agglomerates) and fine species (obviously of compact morphology). It seems that different mineral species are coexisting in the clay powder (see Fig. 1,a). SEM images demonstrated that the Na-bentonite powder consist of unequally sized particles, probably formed by agglomeration. Magnification discloses a large number of small species distributed on the surface of the larger particles. On the other hand, there are also layer structured agglomerates recognizable (sse Fig. 1,b).

Also, chemical composition of Na-bentonite clay analyzed using XRD (Fig. 2,a) and EDX analysis (see Fig. 2,b). Chemical composition of bentonite clays mined from this deposit has the following characteristics (see Fig. 2,a,b).

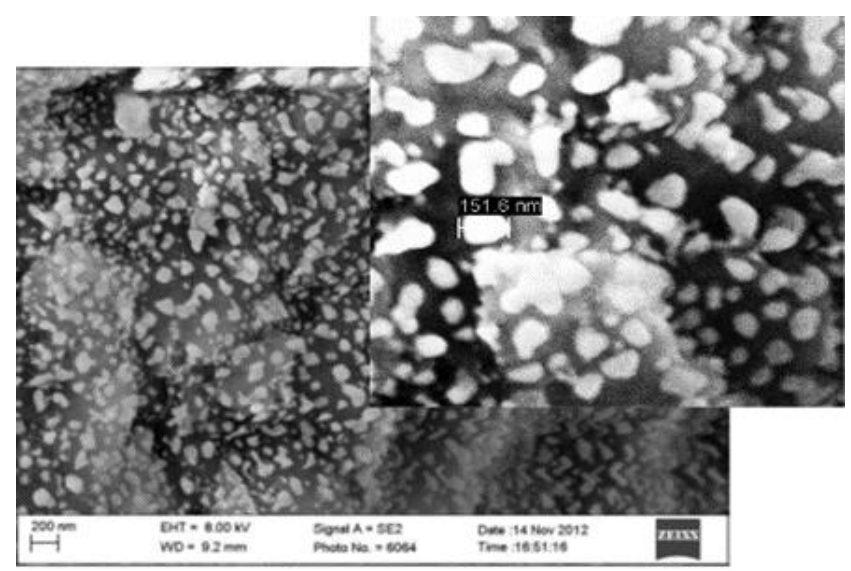

$a$

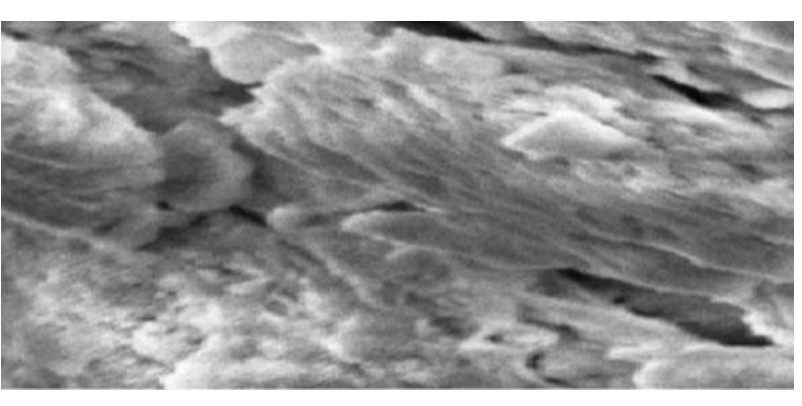

$b$

Fig. 1. SEM image of Na-bentonite clay: a-overall distributed fine particles; $b$-layer structured agglomerates 

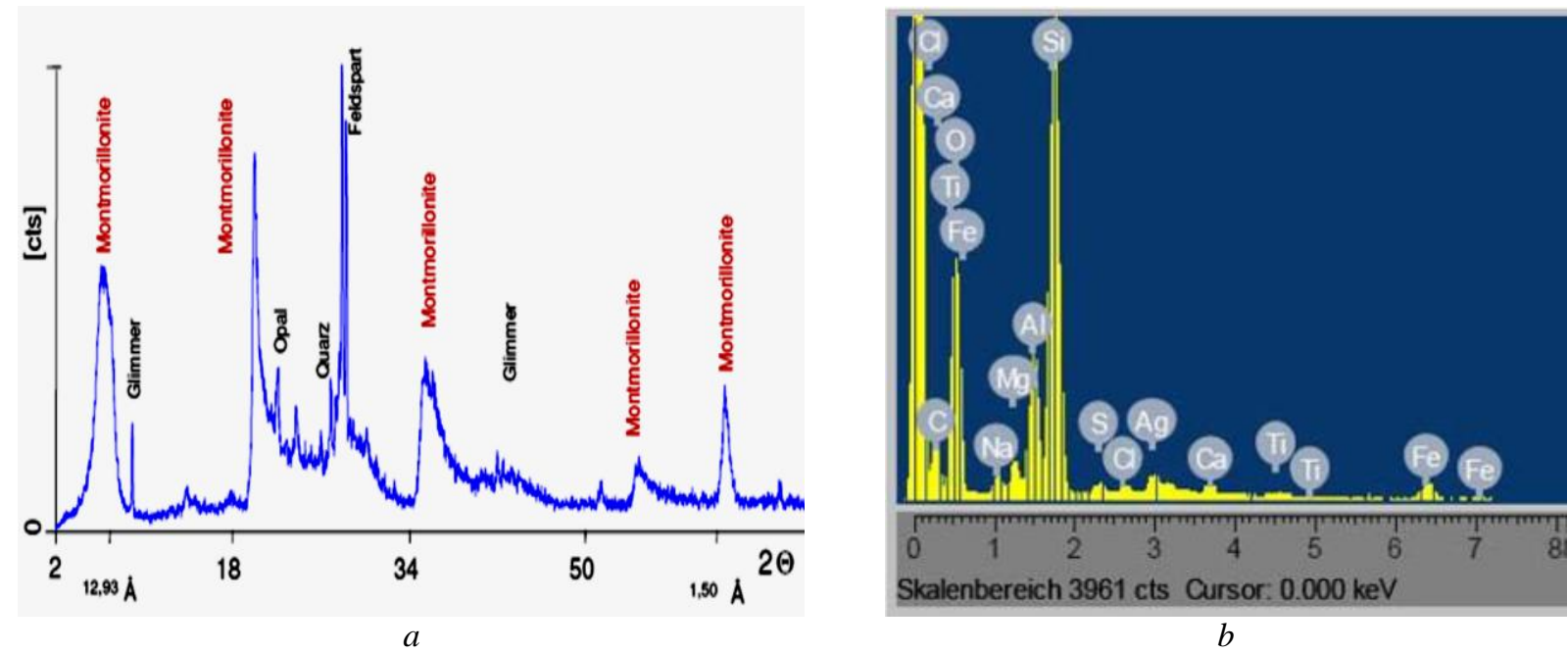

Fig. 2. Chemical composition of bentonite clays: $a-X R D$ diagram of Na-bentonite clay; $b-$ EDX spectra of Na-bentonite clay

The XRD plot shows that montmorillonite has the highest content in the clay samples (see Fig. 2,a). EDX spectra confirm the presence of sulfides in Alpoide clay.
FT-IR spectra of unirradiated Na-bentonite clay is shown in Fig. 3 and all the important bands and their assignments are listed in Table 2.

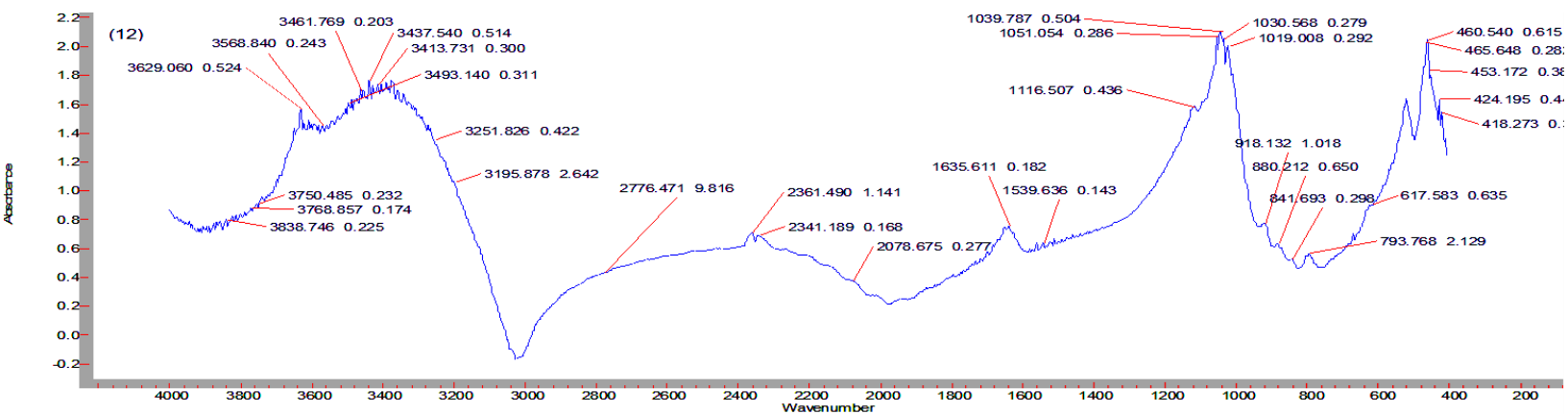

Fig. 3. FT-IR spectra of unirradiated Na-bentonite clay

Table 2

Position of absorption bands in the IR spectrum of unirradiated Na-bentonite clay

\begin{tabular}{|c|c|}
\hline Wave number, $\mathrm{cm}^{-1}$ & Atomic group \\
\hline 3750 & $-\mathrm{OH}$ (structural) \\
3628 & $-\mathrm{OH}$ (structural) \\
3413 & $\mathrm{H}_{2} \mathrm{O}$ (absorption) \\
3437 & $\mathrm{H}_{2} \mathrm{O}$ (absorption) \\
3461 & $\mathrm{H}_{2} \mathrm{O}$ (absorption) \\
2078 & $\mathrm{H}_{2} \mathrm{O}$ \\
2341 & $\mathrm{H}_{2} \mathrm{O}$ \\
2361 & $\mathrm{H}_{2} \mathrm{O}$ \\
1635 & $\mathrm{H}_{2} \mathrm{O}$ \\
1030 & $\mathrm{Si}-\mathrm{O}$ \\
1039 & $\mathrm{Si}-\mathrm{O}-\mathrm{Si}$ \\
460 & $\mathrm{Si}-\mathrm{O}-\mathrm{Si}$ \\
465 & $\mathrm{Si}-\mathrm{O}-\mathrm{Si}$ \\
424 & $\mathrm{Si}-\mathrm{OH}$ \\
& $\mathrm{Si}-\mathrm{O}$ \\
790 & $\mathrm{Si}-\mathrm{O}$ \\
841 & $\mathrm{Al}-\mathrm{OH}$ \\
912 & Fe (III)-O in oct. Positions \\
\hline
\end{tabular}

Presented below are the noticeable IR spectra of clay samples (irradiated in the range $1 \ldots 57 \mathrm{kGy}$ ). 


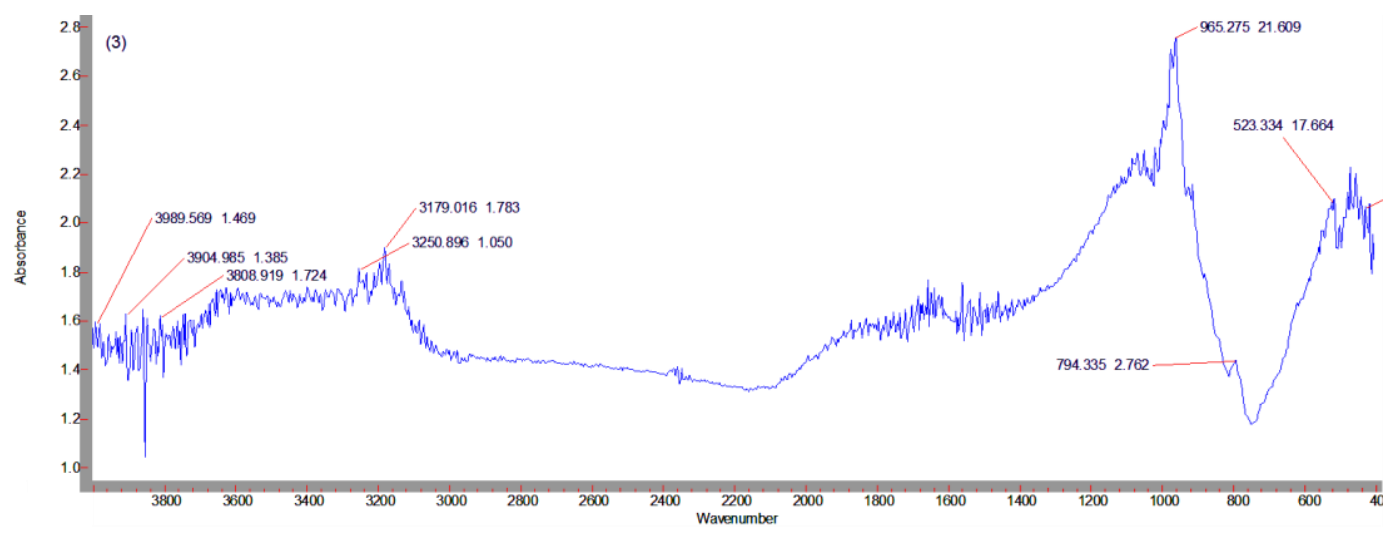

a
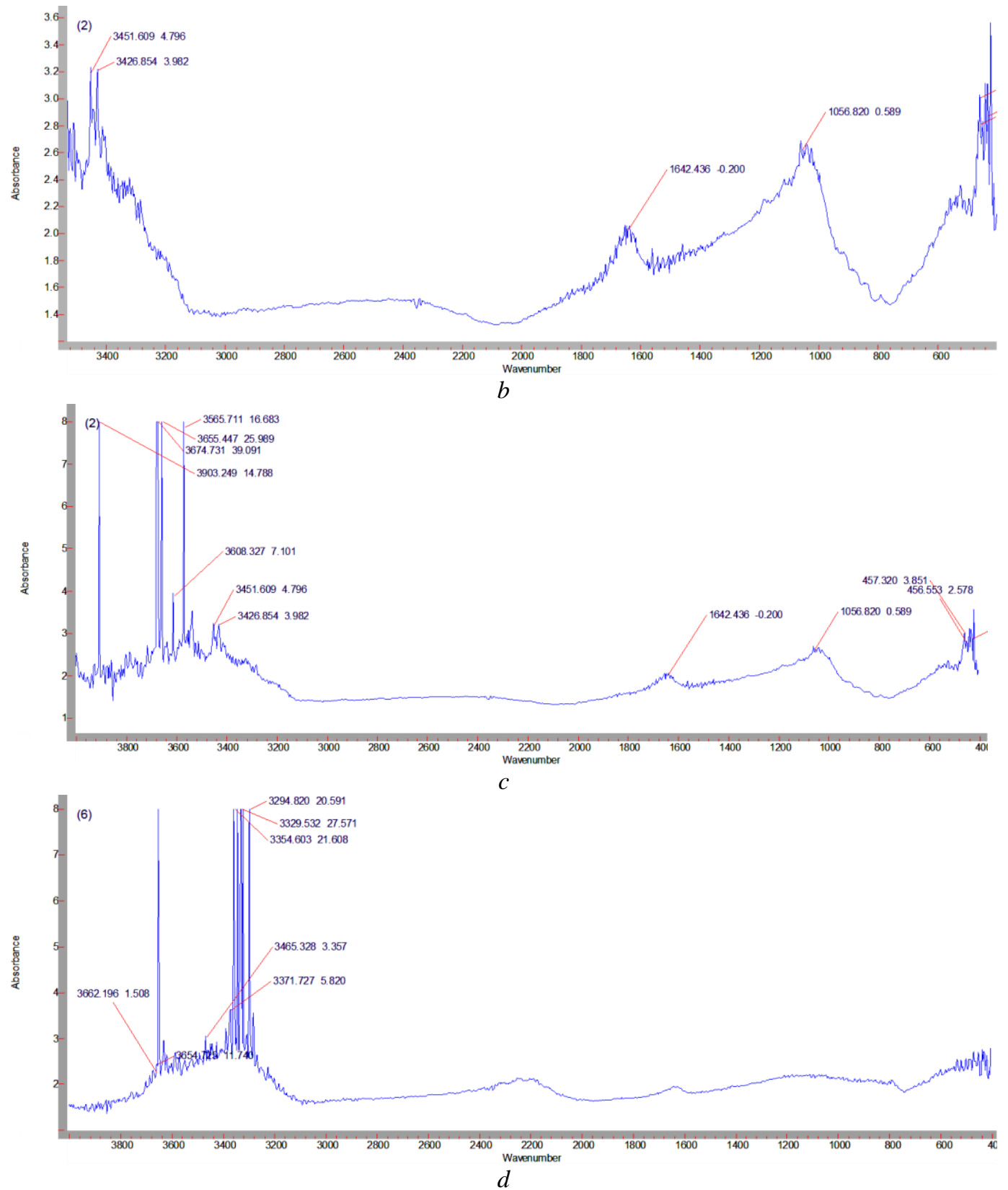

Fig. 4. FT-IR spectra of Na-bentonite clay, irradiated at different gamma radiation doses: $a-3 ; b-a t 6 ; c-28 ; d-57 k G y$

Fig. 4 shows structural alteration in irradiated samples at different doses. After $3 \mathrm{kGy}$ irradiation a new peak appeared at 965 and $523 \mathrm{~cm}^{-1}$ which presented Si-OH and Si-O-Al bands (see Fig. 4,a) A weak loss of "crystallinity" of bentonite could be observed. From 3 up $57 \mathrm{kGy}$ occurs modification of bentonite clay samples (see Fig. 4,a-c). But at dose of $57 \mathrm{kGy}$ take places destruction under ionizing radiation. As can be seen from Fig. 4,d, after $57 \mathrm{kGy}$ irradiation except for 
the destruction of a solid phase of clays, there is radiolysis of pore water.

Fig. 4,a-c shows the modification of bentonite surfaces with $\gamma$-rays. IR spectrum (see Fig. 4,b) is that of the bentonite surfaces modified through hydrogen bonding with $\gamma$-rays at a dose of $6 \mathrm{kGy}$ (see spectrum Fig. 4,c) is that at a dose of $28 \mathrm{kGy}$ (see spectrum Fig. 4,d) at a dose of $57 \mathrm{kGy}$ intercalation of the bentonite through hydrogen bonding of the inner surface hydroxyls with $\gamma$-rays causes a dramatic decrease in intensity of bands at 3693 and $3650 \mathrm{~cm}^{-1}$ attributed to the inner surface hydroxyl groups is observed. Activiation under the conditions at dose of $57 \mathrm{kGy}$ and room temperature, caused the bentonite to show an increase in defect structures. Many studies have been reported, trying to pin down the relations between acid strength and short-and long -range structural factors, such as $\mathrm{Si}-\mathrm{O}-\mathrm{Al}$ angles or $\mathrm{Si}-\mathrm{O}$, Al-O distances, flexibility of the frame-work and electrostatic potencial generated inside the cavities [21, 22].

At present there are few researches done concerning the influence of radioactive irradiation on rock and soils, including clay deposits. Radiation stability of minerals usually reduces through quartz to aluminosilicates: quartz- microcline-kaolin-hydromicamontmorillonites. According to the statements of the theory of radiation damages in a solid body, crystalline structure of minerals in changed owing to interaction among radiating particles and mineral constituent elements, which are disturbed from equilibrium condition at the points of the lattice and may cause the displacement of other elements. Such processes lead to crystalline structure disordering, vacancies making and forming defects on the micro-level, finally all these phenomena cause the change of mineral properties owing to their amorphization special investigations have shown that amorphization of quartz, which is one of the minerals existing in clay (see Fig. 2,a), after being irradiated is accompanied by an increase in its volume to more than $17 \%$. First of all, the irradiation influences on structural bonds existing between minerals and its aggregates.

It is necessary to pay a special attention to radioactive stability of clay minerals, which interlayer bonds usually results from unlike charged surfaces, or cations, which are between the same charged layers. Similar bonds are easily broken down when exposed to radioactive irradiation simultaneously with the structural bonds existing between mineral particles. Change in valent bond vibrations of $\mathrm{Si}-\mathrm{O}$ and $\mathrm{Al}-\mathrm{O}$ inside a layer up to its fracture is observed on long-term radioactive exposure. Besides there is dehydration of crystallization water, and structural water in the form of $\mathrm{OH}^{-}$groups from the crystal lattice. The removal of crystallization impact of chemical, physical-chemical and physical and mechanical properties of clays, the removal of structural water leads to a complete fracture of clay minerals. Na-bentonite clay from Alpoid $(\mathrm{pH}=10)$ may be compared with Cambrian blue clays. Because being part of clay minerals of Lower Cambrian blue clays are represented by high-alkaline minerals, interlayer links destruction will take place at low enough radiation doses. The main structural defects in clay minerals are developed on radiation exposure, which is $10^{5} \ldots 10^{6} \mathrm{~Gy}$. Thus, the process of destruction of silico-alumina nucleus of clay minerals is becoming more active in a particular sequence of cation out let of crystal lattice: $\mathrm{Fe}^{3+}>\mathrm{Ca}^{2+}>\mathrm{Mg}^{2+}>\mathrm{Na}^{+}>\mathrm{K}^{+}>\mathrm{Si}^{4+}$. Except for the destruction of a solid phase of clays, there is radiolysis of pore water, which results in the formation of free radicals and the molecular components causing the change of acid-alkaline and oxidation-reduction conditions in a clay strata. In blue clays organics and sulphids may be oxidized activity while forming the process of radiolysis of pore water at adsorbed doses up $10^{5} \ldots 10^{7}$ Gy EDX spectra confirm existing sulphids in Alpoid clay (see Fig. 2,b). When a comparison is made with other clays in Na-bentonite case the destruction occurred at adsorbed doses $57 . .256 \mathrm{kGy}$ region.

The surface modification of clay minerals especially by gamma-rays, which occurs due to defects, could improve markedly their surface, physical and chemical properties so the modified bentonite clay could be applied as catalysts, adsorbents and so on.

The modification of bentonite clay from Alpoid deposit by gamma-rays creates future possible perspectives. In works [20, 23] were shown that irradiated Na-bentonite clay plays key role for aromatization and isomerization reactions of hydrocarbons.

\section{CONCLUSIONS}

The studies performed by reflection - absorption IR spectroscopy show the modification of Na-bentonite clay by $\gamma$-rays. The modified clays could be used as catalyst for aromatization and isomerization processes. This method is low-cost and environmental - friendly.

The results show that the destruction of Na-bentonite clay minerals was occurred at $57 \mathrm{kGy}$.

\section{REFERENCES}

1. M.S. Nazir, M.H.M. Kassim, L. Mohapatra, M.A. Gilani, M.R. Raza, K. Majeed. Nanoclay Reinforced Polymer Composites. Springer: Singapore, 2016, p. 35-55.

2. K. Müller, E. Bugnicourt, M. Latorre, M. Jorda, Y. Echegoyen Sanz, J.M. Lagaron, O. Miesbauer, A. Bianchin, S. Hankin, U. Bölz. Review on the processing and properties of polymer nanocomposites and nanocoatings and their applications in the packaging, automotive and solar energy fields // Nanomaterials. 2017, N 7, p. 74.

3. G. Rytwo. Clay minerals as an ancient nanotechnology: Historical uses of clay organic interactions, and future possible perspectives // Macla. 2008, N 9, p. 15-17.

4. S.M. Lee, D. Tiwari. Organo and inorganoorgano-modified clays in the remediation of aqueous solutions: An overview // Appl. Clay Sci. 2012, N 59, p. 84-102.

5. M.K. Uddin. A review on the adsorption of heavy metals by clay minerals, with special focus on the past decade // Chem. Eng. J. 2017, N 308, p. 438-462. 
6. M. Jawaid, A.K. Qaiss, R.Bouhfid Nanoclay Reinforced Polymer Composites: Nanocomposites and Bionanocomposites. Springer: Singapore, 2016.

7. I. Savic, S. Stojiljkovic, I. Savic, D. Gajic. Clays and Clay Minerals: Geological Origin, Mechanical Properties and Industrial Applications / Wesley L.R., Ed. Nova Science Publishers: New York, NY, USA, 2014, p. 379-402.

8. E.P. Giannelis. Polymer layered silicate nanocomposites // Adv. Mater. 1996, N 8, p. 29-35.

9. G. Feng, A. Saman, H.Yinghui, J. Yunpeng. A review of the synthesis and applications of polymernanoclay composites // Appl. Sci. 2018, v. 8, N9, p. 1696.

10. A. Negron, S. Ramos, A.L. Bblumenfeld, G. Pacheco, J.J. Fripiat. On the structural stability of montmorillonite submitted to heavy g-irradiation // Clays and Clay Minerals. 2002, v. 50, N 1, p. 35-37.

11. B. Clozel, Th. Allard, J.-P. Muller. Nature and stability of radiation-induced defects in natural kaolinites; new results and a reappraisal of published works // Clays and Clay Minerals. 1994, v. 42, p. $657-$ 666.

12. T.J. Pinnavaia. Intercalated clay catalysts // Science. 1983, v. 220, N 4595, p. 365-371.

13. H. van Olphen. An Introduction to Clay Colloid Chemistry. Wiley Interscience, New York, NY, USA, 2nd edition, 1977.

14. K.G. Bhattacharyya, S. Sen Gupta. Adsorption of a few heavy metals on natural and modified kaolinite and montmorillonite: a review //Advances in Colloid and Interface Science. 2008, v. 140, N 2, p. 114-131.

15. http://www.azbms.tk
16. http://www.azrpi.com/

17. P.E. Belousov. Comparative Characteristic of high-quality bentonite deposits of Russia and some foreign countries // RUDN Journal of Engineering Researches. 2013, N 2, p. 55-61.

18. J. Merkel, B. Planer-Friedrich, C. Wolkersdorfer. Uranium in the aquatic environment. Germany, Springer-Verlag Berlin, Heidelberg, 2002, p. 134-136.

19. M. Plötze, R. Hermanns Stengele, G. Kahr. Alteration of clay minerals-gamma-irradiation effects on physicochemical properties // Applied Clay Science. 2003, v. 23, N 1, p. 195-202.

20. M.K. Ismayilova. Influence of energy transfer in the adsorbed state of the clay at the petroleum radiolysis under gamma radiation at room temperature // Radiation effects and defects in solids. 2020, v. 175, N 5-6, p. 472481.

21. K.P. Schroder, J. Sauer, M. leslie, C.R.A. Catlow, J.M. Thomas. Bridging hydrodyl groups in zeolitic cata-lysts: a computer simulation of their structure, vibratio-nal properties and acidity in protonated faujasites (HYzeolites) // Chem. Phys. Lett. 1992, v. 188, N 3-4, p. 320.

22. P. Ugliengo, A.M. Ferrari, A. Zehina, E. Garrone. Structure and Vibrational Features of Complexes between Unsaturated Hydrocarbons and Acidic Sites in Silica and Zeolites: An ab Initio Study // J. Phys. Chem. 1996, v. 100, N 9, p. 3632-3645

23. M.K. Ismayilova, R.J. Qasimov, M.A. Bayramov, S.Z. Melikova. The effects of low-dose radiation on structural isomerization of gunashli oil's hydrocarbons in presence of bentonite // Jornal of radiation researches. 2020, v. 7, N 1, p. 57-63.

Article received 30.08 .2021

\section{ВЛИЯНИЕ ГАММА-ОБЛУЧЕНИЯ НА СИЛИКАТНЫЕ СЛОИ НАНОСТРУКТУРИРОВАННОГО NА-БЕНТОНИТА ПРИ КОМНАТНОЙ ТЕМПЕРАТУРЕ М.К. Исмаилова}

Изучено воздействие гамма-лучей на наноструктурированную бентонитовую глину из месторождения Альпоид. Влияние высоких доз (до 256 кГр) гамма-излучения на структуру в монтмориллоните исследовано с помощью инфракрасной спектроскопии. После облучения при дозе 57 кГр существенных изменений не наблюдалось. Было отмечено небольшое изменение содержания воды, но оно не носит систематического характера. Результаты показывают, что структура монтмориллонита может накапливать высокие дозы радиации с повреждением. Ожидается, что модификации, которые, скорее всего, будут вызваны излучением, будут находиться внутри силикатных слоев. Морфология нанокомпозитов была изучена с помощью сканирующей электронной микроскопии. В данной работе влияние ионизирующего излучения на Naбентонитовую глину исследовано методом FT-IR. Эти спектры показывают пригодность ИК-Фурье-анализа поверхностей минералов и изменения спектров, вызванные поверхностными явлениями.

\section{ВПЛИВ ГАММА-ОПРОМІНЕННЯ НА СИЛІКАТНІ ШАРИ НАНОСТРУКТУРОВАНОГО Na-БЕНТОНІТУ ПРИ КІМНАТНІЙ ТЕМПЕРАТУРІ \\ М.K. Ісмаӥлова}

Вивчено вплив гамма-променів на наноструктуровану бентонітову глину з родовища Альпоід. Вплив високих доз (до 256 кГр) гамма-випромінювання на структуру в монтморилоніті досліджено за допомогою інфрачервоної спектроскопії. Після опромінення при дозі 57 кГр істотних змін не спостерігалося. Була відзначена невелика зміна вмісту води, але вона не має систематичного характеру. Результати показують, що структура монтморилоніту може накопичувати високі дози радіації з пошкодженням. Очікується, що модифікації, які, швидше за все, будуть викликані випромінюванням, перебуватимуть всередині силікатних шарів. Морфологія нанокомпозитів була вивчена за допомогою скануючої електронної мікроскопії. У цій роботі вплив іонізуючого випромінювання на Na-бентонітову глину досліджено методом FT-IR. Ці спектри показують придатність ІЧ-Фур'є-аналізу поверхонь мінералів і зміни спектрів, які викликані поверхневими явищами. 